\title{
The correction of occlusal vertical dimension on tooth wear
}

\section{Rostiny}

Department of Prosthodontic

Faculty of Dentistry Airlangga University

Surabaya - Indonesia

\begin{abstract}
The loss of occlusal vertical dimension which is caused by tooth wear is necessarily treated to regain vertical dimension. Correctional therapy should be done as early possible. In this case, simple and relatively low cost therapy was performed. In unserve loss of occlusal vertical dimension, partial removable denture could be used and the improvement of lengthening anterior teeth using composite resin to improve to regain vertical dimensional occlusion.
\end{abstract}

Key words: vertical dimension occlusion, tooth wear

Correspondene: Rostiny, c/o: Bagian Prostodonsia, Fakultas Kedokteran Gigi Universitas Airlangga. Jln. Mayjend. Prof. Dr. Moestopo no. 47 Surabaya 60132 , Indonesia.

\section{INTRODUCTION}

Worn teeth due to tooth wear could be pathologically caused by endogen and exogen factors. Tooth wear could be caused by parafunction abnormality and its occurrence is estimated three times faster than physiological tooth wear.

The etiology of tooth wear could be classified as mechanical and chemical. Mechanical tooth wear are attrition and abrasion, while chemical tooth wear is erotion. ${ }^{2}$ Another factor which has essential role on causing tooth wear is the prolonged posterior teeth loss which are not replaced. Thus the patient tends to chew using anterior teeth, which resulting the anterior teeth worn. It makes the patient loss the occlusal vertical dimension. The loss of posterior teeth could generally cause abrasion and attrition in anterior teeth. It makes replacement of mandible to anterior position and the mastication force of anterior teeth become heavier. The anterior teeth might worn and mobile.

The loss of occlusal vertical dimension because of physiological factor could be compensated by teeth eruption and continuous growth of alveolar bone. ${ }^{3}$ Severe tooth wear could cause morphological change of occlusal tooth, decrease the vertical dimension, pulp pathology, occlusal disharmony and change the masticatory function. In this condition, more complex therapies are needed such as: endodontics, periodontics, and full coronal converage.

To establish the diagnosis, it is necessary to understand the etiology of tooth wear such as: bruxism, diet, gastro esophageal disease, eating disorders, xerostomia, amelogenesis and dentinogenesis imperfecta. ${ }^{4,5}$ Besides the etiology, clinical parameter and classification or type of tooth wear are necessary to be considered.

Several methods could be applied to determine the occlusal vertical dimension. The first method is Niswonger, occlusal vertical dimension could be achieved from vertical jaw dimension in rest position subtracted free way space
(2-4 mm). ${ }^{6}$ The second method is Willis, the distance between the pupil of the eye and the rima oris is equal to the distance between nasal base to the point below the chin when the teeth or bite wall contacted. ${ }^{7}$ The third method is Silverman (phonetics): utter the phonetic consisting " $\mathrm{S}$ " (e.g. "Yess"), the distance from incisal edge to maximum occlusal contact is recorded while saying it. The incisal gap is approximately 2-4 mm identical with freeway space.

Prolonged loss of occlusal vertical dimension would influence face appearance. The face looks older and in severe condition might cause angular cheilitis. In case of occlusal vertical dimensional loss due to tooth wear, therapy is needed to regain the vertical dimension. The therapies such as: lengthening the crown, orthodontical tooth movement and reposition therapy are efficient and effective to correct dimensional vertical loss.

The aim of this study was to reported that loss of occlusal vertical dimension due to tooth wear is necessary to be treated as early as possible by simple and relative cheap therapy.

\section{CASE}

A 44 year old female patient came to Dental Clinic of Faculty of Dentistry Airlangga University to have partial denture on upper and lower jaw, to regain masticatory and esthetic function. Some caries teeth had been extracted prior the visit and the last extraction was done two years ago. The patient never use denture before.

Intra oral examination: the loss teeth were: $15,17,22$, $23,24,36,37,43$, and 47; gangrene radix: 16, 27, 35, 45, 46; caries on: 26, 31, 32; worn teeth 34, 33, 32, 31, 41, 42, 44 (Figure 1-4), deep bite anterior relation.

Dimensional vertical occlusion examination was done by using Niswonger and Willis method with attention given to the facial appearance. ${ }^{6,7}$ Vertical dimension of occlusion 


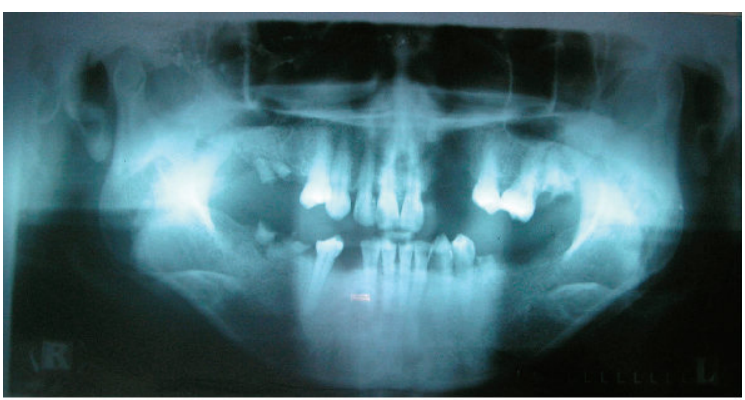

Figure 1. Panoramic rontgenographic of patient.

measurement result was: $63 \mathrm{~mm}$, in rest position was $69 \mathrm{~mm}$. The measurement result showed loss of occlusal vertical dimension. Based on the estimation, rest position occlusion was $69-63 \mathrm{~mm}=6 \mathrm{~mm}$, then subtracted by freeway space and the result was $6-4 \mathrm{~mm}=2 \mathrm{~mm}$.

\section{CASE MANAGEMENT}

Vertical occlusal correction was done by increasing the dental crown length $2 \mathrm{~mm}$ at 34, 33, 32, 31, 41, 42, and 44 using resin composite (A3) and inserting acrylic partial denture on upper and lowerjaw (Figure 5, 6, 8). Evaluation was done 2 weeks after correction no complaint of pain in temporo mandibular joint was reported. Teeth extraction in 16, 27 35, 45, and 46. Rest occlusal preparation on distal 14, mesial 25, 34 and mesial 44. Lengthening teeth crown, the material, long life the material and the possibility of color alteration, schedule of visiting and financial were discussed with the patient. For individual tray preparation, the jaw was impressed with stock tray using irreversible hydrocolloid impression material. The impression result was filled with gypsum type 1 to make diagnostic model and used to make individual tray using self cured acrylic. The lower jaw were impressed using individual tray with elastomer impression material. The impression was filled with gypsum type III and used as working model. The working model was surveyed to decide maximum contour where clamer should be placed. Bite wall was made in master model and horizontal jaw relation was done (Figure 7). The master model was mounted in semi adjustable articulator, teeth arrangement was performed and further, the patient was recommended to try the denture wax. In this case, the denture construction was partially removable using acrylic. Three finger wrought wire in 14 and 24 and two finger wrought wire with rest mesial in 34 and 44 after the patient agreed and continued by acrylic process during the trial of partial removable acrylic denture, occlusal correction was done using articulating paper to perform adjustment to achieve stable occlusion, then the removable denture was inserted.

\section{DISCUSSION}

The patient did not realize that tooth wear without therapy could develop to be mandibular disturbance and occlusion, there fore early therapy is necessarily done to keep the rest of the teeth has long as possible in oral cavity. Correction with the increasing of teeth occlusal to regain occlusal vertical dimension could result less stable occlusion. It is not recommended to change the

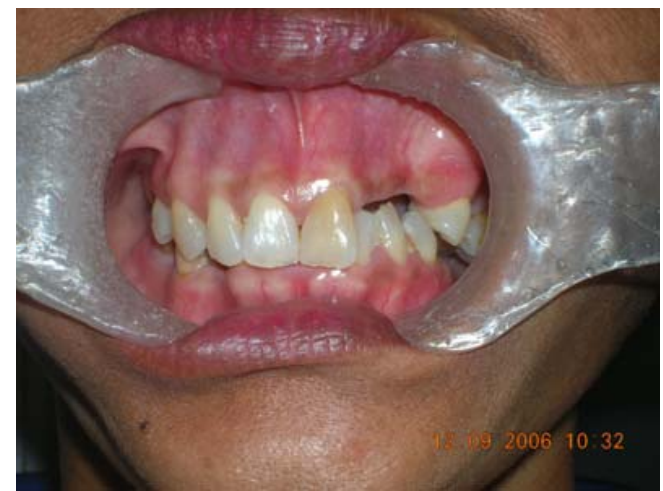

Figure 2. The teeth in occlusion stage in initial examination.

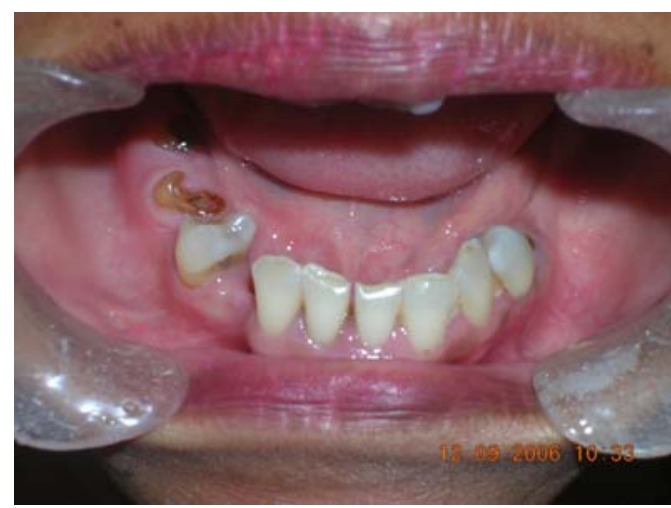

Figure 3. The teeth condition in lower jaw.

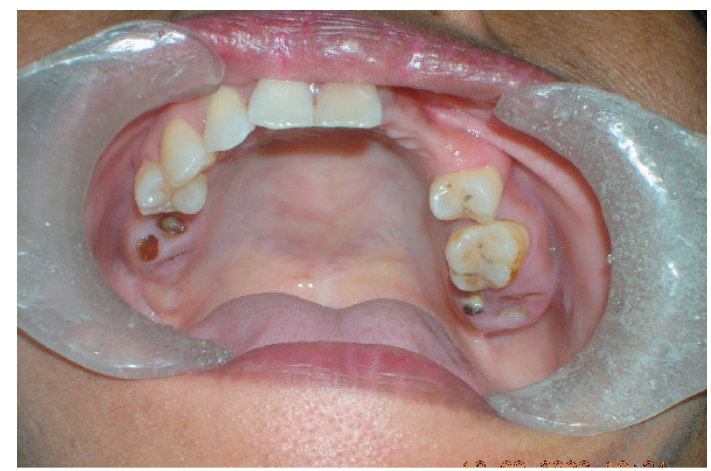

Figure 4. The teeth condition in upper jaw. 


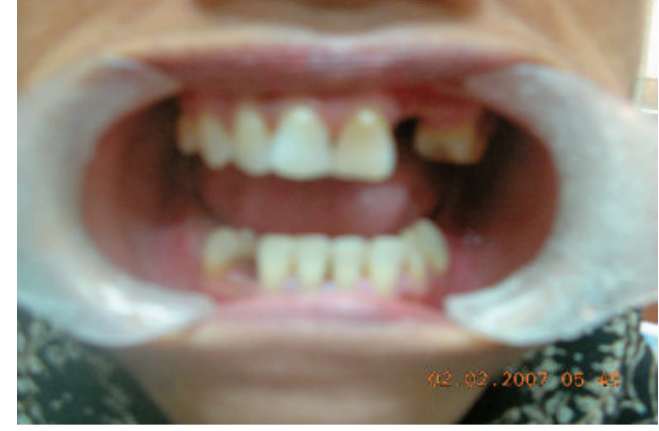

Figure 5. The teeth in lower jaw after restoration was made.

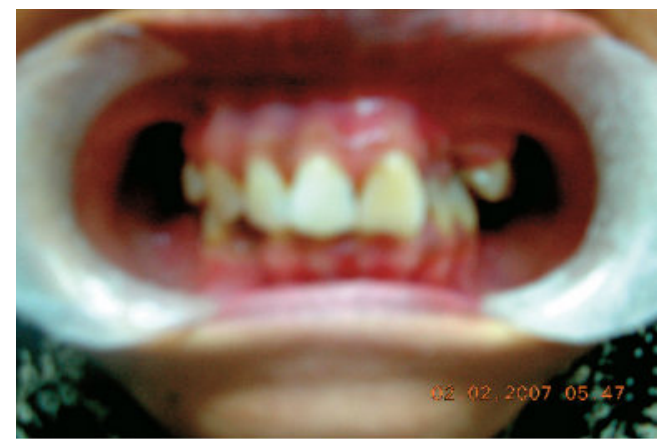

Figure 6. Occlusion of teeth in lower and upper jaw after restoration.

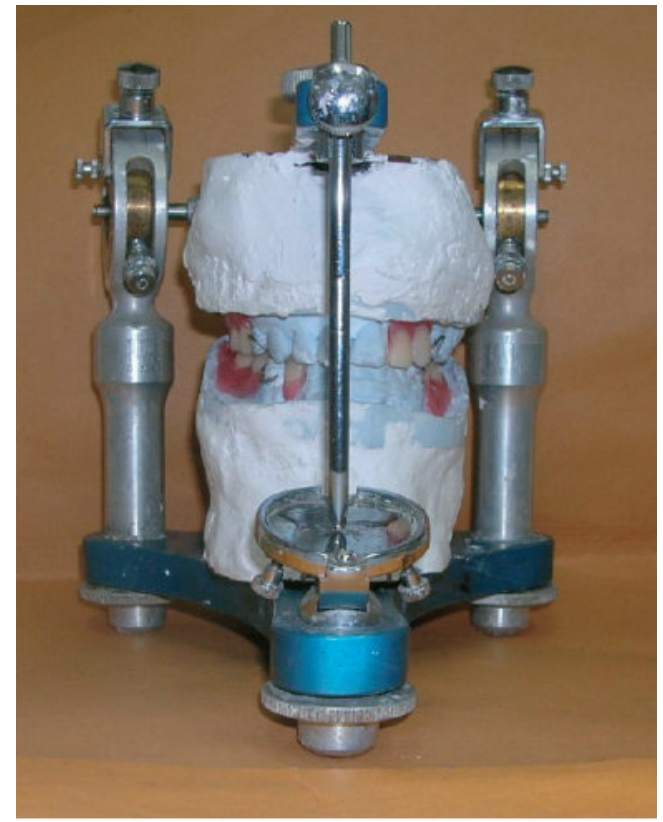

Figure 7. Mounting master model and teeth arrangement in semi adjustable articulator.

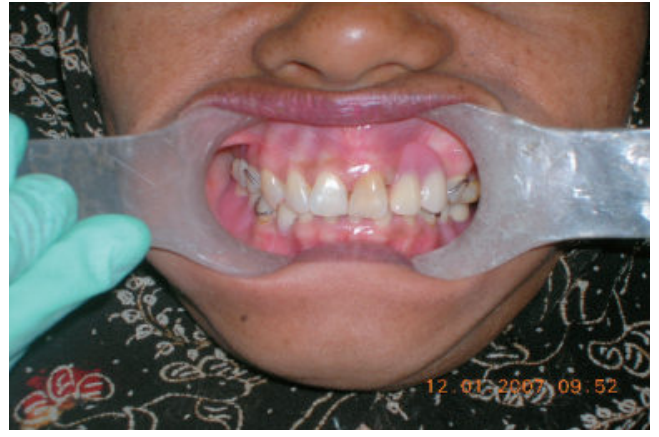

Figure 8. Insertion of the denture.

patient's pattern of dynamic occlusion. It is advisable that the addition of occlusion is about $1-1.5 \mathrm{~mm}$ during the restoration to improve occlusal vertical dimension, if it is higher resulting in unstable occlusion. To obtain the association between proper occlusion and the stability of partial removable denture, occlusion contact should occur simultaneously with working contact of natural teeth so stress/load would be spread equally on the whole surface. ${ }^{10}$ This condition could be obtained by doing occlusal adjustment on the patient. If the correction of occlusal vertical done periodically. In this case, plate could be used to increase the occlusal vertical dimension.

Basically, the correction of occlusal vertical dimension should be done according to the estimation of occlusal vertical dimension loss is not accurate. The increasing of occlusal vertical dimension would possibly occur. Excessive increase of occlusal vertical dimension could result freeway space loss, inflammation of tissue under the removable denture, muscle pain, resorption in residual alveolar bone, horse sound, p, b, m sound would be disturbed because the lips are difficult to close, the increase symptom of temporo mandibular joint syndrome due to the load on the tissue associated with the joint.

In the case of occlusal vertical dimensional correction, is advisable to be done using adjustable articulator or semi adjustable. This type of articulator has advantage such as: the distance between the condile of lower jaw and upper jaw could be moved with the same distance in articulator. By using articulator it could be determined anatomical artificial teeth, the inclination of occlusion plane and lateral movement in which it is almost the same with the patient could be determined. If adjust is needed, there would be small mistake found or even no mistake at all when trying denture.

Occlusal vertical dimension correction with the increase of occlusal needs examination, evaluation and periodical occlusal adjustment until stable occlusion is achieved are necessary. Removable denture could be used to restore and to improve occlusal functional occlusal comfort, improve aesthetic, stabilize and relieve TMJ syndrome ${ }^{12}$ and improve occlusal damage due to tooth wear. ${ }^{8,13}$ 
As conclusion partial removable denture could be used in mild occlusal vertical dimensional loss and the improvement the height of incisal anterior teeth to regain dimension occlusion vertical.

\section{REFERENCES}

1. Xhonga FA. Bruxism and its effect on the teeth. J Oral Rehabil 1997; 4:65-67.

2. Glossary of Prosthodontic Terms. J Prosthet Dent 1999; 81: 39-110.

3. Verret RG. Analyzing the etiology of an extremely worn dentition. J Prosthodont 2001; 10:224-33.

4. Smith BG, Bartlett DW, Robb NG. A comparison of patterns on tooth wear with aetiological factors. J Prosthet Dent 1997; 78:367-72.

5. Ganddini MR, Mardini M, Graser GN, Almog D. Maxillary and mandibular overlay removable partial dentures for the restoration of worn teeth. J Prosthet Dent 2004; 91:210-4.
6. Hickey JC, Zarb GA, Bolender CL. Boucher's prosthodontic treatment of edentulous patients. $10^{\text {th }}$ ed. St Louis: The CV Mosby Co; 1990. p. 237-76.

7. Sharry JJ. Complete denture prosthodontics. $3^{\text {rd }}$ ed. New York: McGraw-Hill Book Co; 1974. p. 211-3.

8. Dawson PE. Evaluation, diagnosis and treatment of occlusal problems. Saint Louis: The CV Mosby Co; 1974. p. 275-85.

9. Turner KA, Missirlian DM. Restoration of the extremely worn dentition. J Prosthet Dent 1984; 52:467-74.

10. Haryanto AG. Buku ajar ilmu geligi tiruan sebagian lepasan. Jilid I. Jakarta: Hipokrates; 1991. p. 52-55.

11. Grant AA, Johnson W. Removable denture prosthodontics. $2^{\text {nd }} \mathrm{ed}$. Edinburgh, London, Madrid, Melbourne, New York, Tokyo: Churchill Livingstone; 1992. p. 71-7.

12. Pudjirochani E. Over closure dan permasalahannya di bidang prostodonsia. Majalah Kedokteran Gigi (Dental Journal) 200 October-Desember; 34(4):161-63.

13. Ash MM, Ramfjord S. Occlusion. $4^{\text {th }}$ ed. Philadelphia: WB Saunders Co; 1995. p. 1-75. 